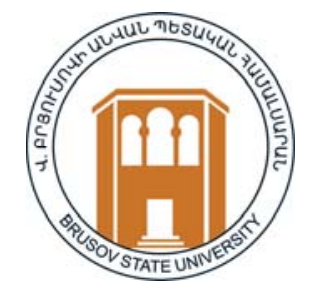

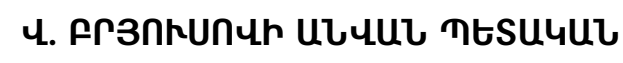
CUUULUURUL

ГОСУДАРСТВЕННЫЙ УНИВЕРСИТЕТ

ИМЕНИ В. БРЮСОВА

BRUSOV STATE UNIVERSITY

คulคtr

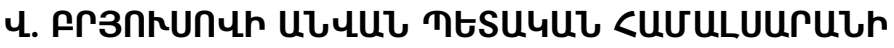
ВЕСТНИК ГОСУДАРСТВЕННОГО УНИВЕРСИТЕТА ИМЕНИ

B. БРЮСОВА

BULLETIN OF BRUSOV STATE UNIVERSITY

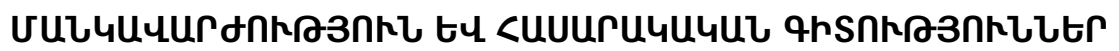

ПЕДАГОГИКА И СОЦИАЛЬНЫЕ НАУКИ

PEDAGOGY AND SOCIAL SCIENCES

2(55)

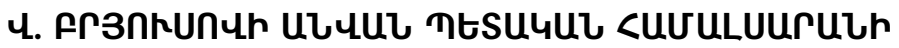

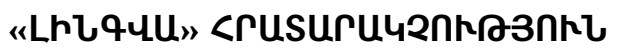

เГヒบuし - 2021 
DOI: $10.51307 / 182931072015233260 / 21.2-223$

\section{ON THE FUNCTIONALITY OF RISK MANAGEMENT FRAMEWORKS AT THE UNIVERSITIES}

\section{SAMVEL HOVHANNISYAN, SVETLANA KARAPETYAN}

Keywords: risk management, risk management framework, academic environment, educational environment, academic risks, and research risks

Internal and external environmental factors and modern-day economic, social and educational trends have led to the necessity for universities to adopt new approaches and policies towards the implementation of their statutory goals and functions. The mentioned factors have entailed the need of integrating risk management into the strategic, operational, and academic processes of universities, thus managing the probable impact of possible external and internal risks on performance effectiveness, on preserving their competitiveness and gaining competitive advantage. With the overall aim of effectively integrating risk management into the corresponding functional processes, a set of policies, procedures, and structures should be developed and assimilate into the risk management framework in order to ensure a systematic approach towards risk management.

Conditioned by the unpredictable and highly changeable political, economic, social, and legal environments, risk management has become even more important for educational institutions from the perspective of increasing efficiency, sustaining competitiveness, and securing competitive advantage. Risk management, therefore, should be integrated into the processes of strategic management and should be viewed as an integral precondition of effective strategic management. To secure the effective implementation of statutory goals and functions, as well as to ensure the competitiveness and possibilities of gaining competitive advantages, universities are conditioned to develop and implement proper strategies, policies, and procedures aiming to provide effective management of risks encountered during their operations.

The overarching objective of this article is to define risk management at universities and to describe the concept of the functionality of university risk management framework as a precondition of effective strategic management. The conceptual propositions are based on the comprehensive desk review of the 
targeted bets practice from the benchmarked universities in Australia, Canada, and the USA.

The concept of risk management can be defined as a coordinated and universal method that is designed to identify, coordinate and respond to the risk factors that can hinder the achievement of the main goals and objectives of the organization (PMI 2013). Risk management can be characterized as a process structured to mitigate or eliminate risks connected with special events or reduce their impact on certain kinds of activities and operations of the organization. It is defined as a process that intends to assist institutions to understand, assess and develop relevant action plans related to all the risks, thus increasing the possibility of success and decreasing the probability of failure (Institute of Risk Management 2002). Risk management can be viewed as a process, the goal of which is an effective balance between recognizing opportunities and reducing vulnerabilities and losses. It is an integral component of management practice and a vital constituent of effective corporate governance (European Network and Information Security Agency 2006: 1).

Based on the presented definitions it is possible to suggest a comprehensive definition of the concept. Risk management is a planned and structured set of processes that intends to contribute to the proper decisionmaking processes and procedures to identify, classify, quantify, evaluate, mitigate and eliminate risks. Risk management is an ongoing process that should be implemented at all levels and integrated into all functions and activities of the university in order to prevent any precarious condition, a probabilistic event or potential source of an undesirable event or effect with the potential for damage, failure or undesirable outcome. Risks are typical to all kinds of human activities. With the development of human society the concept of risk has also evolved receiving diverse emphases at different times. The concept has been discussed from various perspectives, which unveils the reason of abundance and diversity of its definitions in the professional literature.

Table 1. Definitions of risks.

\begin{tabular}{|l|l|}
\hline \multicolumn{1}{|c|}{$\begin{array}{c}\text { Sources in } \\
\text { Chronological } \\
\text { Sequence }\end{array}$} & \multicolumn{1}{c|}{ Definitions } \\
\hline Lowrance (1976) & $\begin{array}{l}\text { Risk is a measure of the probability and severity of } \\
\text { adverse effects. }\end{array}$ \\
\hline $\begin{array}{l}\text { Kaplan and Garrick } \\
\text { (1981), Kaplan (1991) }\end{array}$ & $\begin{array}{l}\text { Risk is defined as a set of scenarios, each of which } \\
\text { has a probability and a consequence. }\end{array}$ \\
\hline $\begin{array}{l}\text { Chapman and } \\
\text { Cooper (1983) }\end{array}$ & $\begin{array}{l}\text { Risk can be seen as the possibility of economic or } \\
\text { financial losses or gains, as a consequence of the }\end{array}$ \\
\hline
\end{tabular}




\begin{tabular}{|c|c|}
\hline & $\begin{array}{l}\text { uncertainty associated with pursuing a course of } \\
\text { action. }\end{array}$ \\
\hline BBA et al. (1999) & $\begin{array}{l}\text { The concept of risk comprises positive and negative } \\
\text { consequences of an event, which may affect the } \\
\text { achievements of strategic, operational, and financial } \\
\text { objectives of a company. }\end{array}$ \\
\hline Cabinet Office (2002) & $\begin{array}{l}\text { Risk refers to the uncertainty of outcome, of actions, } \\
\text { and events. }\end{array}$ \\
\hline $\begin{array}{l}\text { Institute of Risk } \\
\text { Management (2002) }\end{array}$ & $\begin{array}{l}\text { Risk is the combination of the probability of an event } \\
\text { and its consequence. Consequences can range from } \\
\text { positive to negative impact. }\end{array}$ \\
\hline $\begin{array}{l}\text { Rosa (2003 in } \\
\text { Habegger 2008) }\end{array}$ & $\begin{array}{l}\text { Risk is a situation or an event where something of } \\
\text { human value is at stake and where the outcome is } \\
\text { uncertain. }\end{array}$ \\
\hline $\begin{array}{l}\text { Orange Book from } \\
\text { HM Treasury (2004) }\end{array}$ & $\begin{array}{l}\text { Uncertainty of outcome, within a range of exposure, } \\
\text { arising from a combination of the impact and the } \\
\text { probability of potential events. }\end{array}$ \\
\hline Campbell (2005) & Risk equals the expected disutility. \\
\hline Renn (2005) & $\begin{array}{l}\text { Risk is an uncertain consequence of an event or an } \\
\text { activity with respect to something that humans value. }\end{array}$ \\
\hline $\begin{array}{l}\text { Helsloot, Jong (2006: } \\
\text { 143) }\end{array}$ & Risk is probability times effect. \\
\hline Aven (2007) & $\begin{array}{l}\text { Risk is equal to the two-dimensional combination of } \\
\text { events/ consequences and associated uncertainties } \\
\text { (will the events occur and what will be the } \\
\text { consequences). }\end{array}$ \\
\hline Costard (2008) & $\begin{array}{l}\text { Risk is the likelihood of occurrence and the } \\
\text { magnitude of consequences of a specified hazard } \\
\text { being realized. }\end{array}$ \\
\hline $\begin{array}{l}\text { ISO Guide } 73 \\
\text { ISO } 31000 \quad \text { (2009) }\end{array}$ & $\begin{array}{l}\text { Effect of uncertainty on objectives. An effect may be } \\
\text { positive, negative, or a deviation from the expected. } \\
\text { Also, the risk is often described by an event, a } \\
\text { change in circumstances, or a consequence. }\end{array}$ \\
\hline $\begin{array}{l}\text { National Association } \\
\text { of College and } \\
\text { University Business } \\
\text { Officers (2009) }\end{array}$ & $\begin{array}{l}\text { Risk is any issue that impacts an organization's } \\
\text { ability to meet its objectives. }\end{array}$ \\
\hline $\begin{array}{l}\text { Emblemsvag (2010: } \\
\text { 253) }\end{array}$ & $\begin{array}{l}\text { Risks arise due to decisions made, while uncertainty } \\
\text { is due to lacking information. }\end{array}$ \\
\hline
\end{tabular}




\begin{tabular}{|l|l|}
\hline MSISO 31000 (2010) & $\begin{array}{l}\text { Risk is the effect of uncertainty on objectives and it } \\
\text { aids decision-making by taking account of } \\
\text { uncertainty and its effect on achieving objectives and } \\
\text { assessing the need for any action. }\end{array}$ \\
\hline Tuncel, Alpan (2010) & $\begin{array}{l}\text { Risk can be defined as an uncertain event or set of } \\
\text { circumstances that, should it occur, will affect the } \\
\text { achievement of one or more objectives. }\end{array}$ \\
\hline Bakr et al. (2012) & $\begin{array}{l}\text { Risk means that uncertainty can be expressed } \\
\text { through probability. }\end{array}$ \\
\hline Ennouri (2013) & $\begin{array}{l}\text { Risk is a probabilistic event that can exist and affect } \\
\text { the activity of an organization positively (opportunity) } \\
\text { or negatively (hazards). }\end{array}$ \\
\hline IRGC (2017: 14) & $\begin{array}{l}\text { Risk is hence a composition of the potential to cause } \\
\text { harm by the risk agent, the possibilities of being } \\
\text { exposed to this agent and the vulnerability of the } \\
\text { risk-absorbing system (amount of stress that the } \\
\text { system can tolerate). Furthermore, risk expresses } \\
\text { the relative likelihood that such harm is experienced. }\end{array}$ \\
\hline $\begin{array}{l}\text { Project Management } \\
\text { Institute (2017) }\end{array}$ & $\begin{array}{l}\text { A risk is an uncertain event or condition that, if it } \\
\text { occurs, has a positive or a negative effect on (a } \\
\text { project's) objectives. }\end{array}$ \\
\hline
\end{tabular}

Summarizing the mentioned definitions it is possible to suggest an overall definition of risk, characterizing it as a possible loss or opportunities that can impact the capability of an institution of implementing its statutory goals and functions. Differentiated from other institutions operating in the economy and society and aiming to satisfy the educational need of people with social and economic development commitments, universities have encountered new challenges, which assume to maintain competitiveness and gain a competitive advantage at national and international markets effectively managing risks along the way.

Unlike other institutions, universities face other challenging risks that involve the perception of the quality of an educational program, the attraction and retention of students, the quality and upkeep of the academic and residential infrastructure, the completion of capital projects and campaigns, among others (Willson et al. 2010). As a result of the analysis of the professional literature it is possible to target and identify some of the significant risks universities encounter during their activities:

- dependency on tuition fees and state funding,

- lack of endowment funds and/or lack of endowment returns, 
- insufficient recruiting and targeting of both local and international students,

- management of university reputation and brand management of universities and educational programs,

- campus safety,

- low student activism and engagement in decision-making processes,

- low operational efficiency,

- corruption practices of third-party vendors during the tender processes,

- accreditation and licensing of universities,

- facilities and asset management,

- long-term continuity and crisis management,

- talent management and high level of brain drain,

- cybersecurity and security management of student-related data,

- high rates of brain-drain, emigration and limiting state policies,

- increasing economic market requirements,

- market demand of highly competitive students,

- high level of state and local regulations that limits the university autonomies,

- decreasing percentage of research expenditures,

- fraudulent activities in the financial management processes,

- low level of external auditing practices at universities,

- embracing the challenging future and no conceptual framework for the future education and for future research outcome.

In addition to political, economic, social, and legislative risks universities interfere also with the risks in the academic and educational environments. The academic environment is a multicomponent concept that embeds a set of constituents and factors that prepare students for future careers, hone their competences and invest in their personal development opportunities, as well as it boosts their social well-being. The educational environment can be characterized as an important aspect that impacts the motivation and learning outcomes of students (Lai et al. 2009: 1). It is possible to underline the interconnection between academic and educational environments that secures the effectiveness of the learning process, as well as determines the motivation and psychological conditions of the students. It should be mentioned that academic and educational environments suggest a range of risks to the universities influenced by internal and external political, economic, legal, and social factors characterized as academic risks.

Table 2. Definitions of academic risk.

\begin{tabular}{|l|l|}
\hline $\begin{array}{l}\text { Sources in } \\
\text { Chronological }\end{array}$ & Definitions/Characteristics \\
Sequence & \\
\hline
\end{tabular}




\begin{tabular}{|c|c|}
\hline $\begin{array}{l}\text { Raanan (2009: } \\
\text { 44) }\end{array}$ & $\begin{array}{l}\text { Academic risks incorporate research risks, teaching risks, } \\
\text { and quality risks. }\end{array}$ \\
\hline $\begin{array}{l}\text { Toma et al. } \\
(2014: 342)\end{array}$ & $\begin{array}{l}\text { Academic risks involve the following: } \\
\text { - the schooling capacity of the university (the true number } \\
\text { of students); } \\
\text { - admission processes and procedures, } \\
\text { - potential beneficiaries of academic services (high school } \\
\text { graduates); } \\
\text { - the quality of academic study programs; } \\
\text { - the strategy for acquiring their credentials and } \\
\text { authorizations, approvals, and monitoring of the } \\
\text { education programs and the administrative and support } \\
\text { departments that monitor the process, the approach to } \\
\text { research, development, and innovative academic } \\
\text { environment. }\end{array}$ \\
\hline Ochoa (2015) & $\begin{array}{l}\text { The term "academic risk" is defined as the probability of a } \\
\text { student to reach an unfavorable outcome in their studies. } \\
\text { This unfavorable outcome could be as benign as the failure } \\
\text { to submit homework or as costly as dropping-out of a } \\
\text { program. As very little can be done once the unfavorable } \\
\text { outcome has been already reached, especially for the more } \\
\text { costly forms (e.g. failing a course or dropping-out), there is } \\
\text { a strong incentive to being able to estimate the academic } \\
\text { risk of the student, or what is equivalent, predict the } \\
\text { probability that the student will, without intervention, reach } \\
\text { the unfavorable outcome. }\end{array}$ \\
\hline
\end{tabular}

Academic risks are connected with the institution's academic activities. They imply mainly research risks and teaching risks (Raanan 2009: 47). The definitions of research risks are presented below:

Table 3. Definitions of research risks.

\begin{tabular}{|l|l|}
\hline Sources in & Definitions/characteristics \\
Chronological & \\
Sequence & \\
\hline
\end{tabular}




\begin{tabular}{|l|l|}
\hline Raanan (2009: & $\begin{array}{l}\text { Research risks involve the following: } \\
\text { - low-quality research, that is often rejected by the } \\
\text { scientific community, or provides useless, meaningless }\end{array}$ \\
& data; \\
- & research that implies a research project that uses many \\
& resources providing not equivalent result; \\
- research that is detrimental to the environment; & - hazardous research that puts people, equipment, \\
& resources at risk.
\end{tabular}

Closely interconnected with academic risks, teaching risks involve the

following (Raanan 2009: 47):

- teachers, professors, lecturers with low qualifications, who are unable to teach or to use innovative teaching methods;

- insufficient teaching resources, such as lack of teachers, professors, lecturers, teaching assistants, or required teaching equipment, infrastructures and resources;

- unfair or inadequate tests, which do not reveal the true knowledge of students or are extremely difficult for them;

- students, who never or are highly not to complete their studies.

Academic risks can be referred both to risks that prevent the institution from achieving its academic goals and to risks that interfere with the effective implementation of academic processes of the institution risking its academic reputation. Academic risks are interconnected with research risks that imply a set of risks encountered by researchers during their research activity. Research risks constitute different risks (Carter 2007), but not limited to such as: policy/strategy, physical, financial, ethical, human- and animal-associated risks, legal, commercial, staff-related, collaborative, public relations perception-related risks, IT risks, among the main risks.

To manage the introduced risks, universities need a structured and organized system that would assist them in achieving their goals. It should be mentioned that universities cannot address all the present and emerging risks with possible impact on their performance effectiveness, competitiveness, and capability of competitive advantage, but they should be aware of the growing number of threats and negative circumstances that have the potential to imply further risks for universities. To effectively manage the risks they face, universities need to develop and operate risk management frameworks as a systematic and organized structure of risk management.

A risk management framework can be defined as a structure that aims to assist the institution in making reasonable decisions and to ensure the basis for assessing and monitoring the profiles of risks the institution faces. It secures a 
common understanding of risk and promotes a consistent approach towards managing them (Global Partnership for Education 2019: 5). A risk management framework is a group of elements that ensure basis and organizational activities for developing, performing, monitoring, reviewing, and constantly improving risk management processes at all levels of the institution (Government of South Australia: 25). Based on these concepts, this article also present a definition of risk management framework. Risk management framework embeds a set of principles, standards, goals, responsibilities, functions, and policy that assists the higher education institution to identify, assess, manage, monitor, and review the risks that can hamper the implementation of the statutory and strategic goals of the institution. Risk management framework provides a fundamental direction and targeted guidance how to improve risk management practices and activities within the university.

The concept of risk management framework is based on different definitions by from diverse universities and educational areas:

- Carleton University (Carleton University 2009: 9) distinguishes the risk management framework as a critical element of the corporate governance accountabilities of the appropriate bodies and stakeholders of the university. It is universal for all the structural subdivisions of the university, managed and controlled by the bodies to ensure improvement of policies, administrative practices, and internal controls, as well as secure the continuous relevance, security, viability, compliance, and accountability of everyday operations of the university.

- James Cook University of Australia (James Cook University 2020) describes a risk management framework as a set of policies, risk management plans, supporting policies that have a goal to preserve an effective, efficient, and adapted document to manage the risks.

- The University of Sydney (The University of Sydney 2017: 4) establishes risk management as a collection of documents required by the appropriate legal grounds that ensure the basis and facilities to develop, implement, monitor, review, and constantly enhance the risk management processes at the university. Risk management framework can be comprised of one or more documents including a university risk appetite and tolerance statement, provisions that assist to recognize and evaluate risks, and those that help to design risk treatment plans and prioritize them, provisions according to which risks are reported, intensified and broadly communicated (The University of Sydney 2017:6).

As a result of the analysis of internal legal documents of the universities it is possible to present the following goals of the risk management framework. The objectives of the risk management frameworks are to: 
- provide shared risk-management related terminology and guidance applying to risk management;

- delegate responsibilities of risk management to different levels;

- recognize critical and relevant risks and opportunities in the activities, processes, and strategy of the university;

- increase the possibility of achieving the statutory and strategic risks;

- assess the risk management processes and activities and ensure that they are functioning effectively;

- ensure transparent communication between different stakeholders related to risk and risk management;

- create a culture of academic integrity and risk awareness;

- promote proactive decision-making;

- enhance operational efficiency and effectiveness.

Risk management framework functionality. The functionality of risk management framework is accomplished through the interaction of different components of the framework, as well as the implementation of strategic risk management processes. The latter ones indicate the probability of the effective realization of the institutional strategy and functions by different structural units, the flexibility of organizational structure, the degree of the purposefulness of resource allocation and use. The functionality of risk management frameworks is guaranteed with the help of evaluation of key performance indicators and four interrelated and sequential stages of strategic risk management mentioned below:

1. planning risk management strategy;

2. implementing risk management strategy;

3. evaluating and monitoring risk management strategy;

4. reviewing and improving risk management strategy.

To ensure the effective operation of risk management framework universities use diverse tools and mechanisms of risk management aiming to continuously improve their activities.

It should be mentioned that in the context of the USA universities, the concept of risk management framework can be defined as a risk management policy and risk management program. Risk management policy is defined as a statement that aims to secure a consistent approach to the risk management processes at all levels at the university (The University of North Carolina at Greensboro 2016). Risk management policy is characterized as a document the aim of which is to illustrate fundamental components of all university policies; to determine how university policies are formed, maintained, and published; and to advance the systematic review of university policies. The policy should be reviewed annually to assure that its exercises are appropriate and achieving their 
designed object (University of Arkansas at Little Rock 2019). A risk management program is defined as a document that recognizes, evaluates, and addresses risks that could induce harm or property loss, or that could prevent the capacity of the university to meet its or reach its objectives (Washington State University 2020).

In the context of the external and internal changable environments and new educational challenges, universities must adopt effective risk management practices and integrate risk management into strategic management as an integral part of it. To achieve this goal, universities need to develop a comprehensive risk management framework, which should include risk management policies, approaches, and mechanisms aiming to ensure effective risk management. Universities need not only to develop a risk management framework but also to ensure its functionality providing a consistent and systemic approach to it. The functionality of the risk management framework, which is achieved by a sequence of actions consisting of certain stages, is a premise of effective risk management and overall strategic management of universities.

\section{REFERENCES}

1. Aven, T. 2007. A Unified Framework for Risk and Vulnerability Analysis and Management Covering both Safety and Security. Reliability Engineering and System Safety. Vol. 92, 745-754.

2. Bakr, A. F., El Hagla, K., Nayer, A., Rawash, A. 2012. Heuristic Approach for Risk Assessment Modeling: EPCCM Application (Engineer Procure Construct Contract Management), Alexandria Engineering Journal (51), 305-323.

3. BBA - British Bankers' Association, International Swaps and Derivatives Association, PricewaterhouseCoopers LLP 1999. Operational Risk: The Next Frontier. RMA. Philadelphia.

4. Cabinet Office 2002. Risk: Improving Government's Capability to Handle Risk and Uncertainty. London: Strategy Unit.

5. Campbell, S. 2005. Determining Overall risk. Journal of Risk Research. Vol. 8, 569 - 581.

6. Carleton University 2009. Risk Management Manual. Canada. https://carleton.ca/financialservices/wp-content/uploads/Risk-ManagementManual-posted-July-26-2009.pdf

7. Carter, I. 2007. Research Risk Assessment in a University. University of Liverpool.

8. Chapman, C. B., Cooper, D. F. 1983. Risk Engineering: Basic Controlled Interval and Memory Models. Journal of the Operational Research Society, 34(1), 51-60. 
9. Costard, S. 2008. Introduction to Risk Analysis and Risk Assessment. RVC, University of London.

10. Emblemsvag, J. 2010. The Augmented Subjective Risk Management Process. Management Decision, 48(2), 248-259. Doi: 10.1108/00251741011022608

11. Ennouri, W. 2013. Risks Management: New Literature Review. Polish Journal of Management Studies. Vol. 8.

12. European Network and Information Security Agency 2006. Risk Management: Implementation Principles and Inventories for Risk Management/Risk Assessment Methods and Tools.

13. Global Partnership for Education 2019. Risk Management Framework and Policy.https://www.globalpartnership.org/sites/default/files/document/file/202 0-08-risk-management-framework-policy.pdf

14. Government of South Australia. 2009. Risk Management Framework. Department for Communities and Social Inclusion. https://dhs.sa.gov.au/ data/assets/pdf_file/0008/9782/risk-management-framework.pdf

15. Helsloot, I., Jong, W. 2006. Risk Management in Higher Education and Research in the Netherlands. Journal of Contingencies and Crisis Management, 14(3), 142-159. Doi:10.1111/j.1468-5973.2006.00490.x

16. HM Treasury 2004. The Orange Book: Management of Risk-Principles and Concepts.

17. Institute of Risk Management 2002. A Risk Management Standard. https://www.theirm.org/media/4709/arms_2002_irm.pdf

18. IRGC. 2017. Introduction to the IRGC Risk Governance Framework, Revised Version. Lausanne: EPFL International Risk Governance Center.

19. ISO Guide 73, ISO 31000:2009(E). Risk Management-Principles and Guidelines. Switzerland.

20. James Cook University 2020. Risk Management Policy. Australia.

21. Kaplan, S. 1991. Risk Assessment and Risk Management - Basic Concepts and Terminology. In Risk Management: Expanding Horizons in Nuclear power and Other Industries. Boston, MA: Hemisphere Publishing Corporation.

22.Kaplan, S., Garrick, B. J. 1981. On the Quantitative Definition of Risk. Risk Analysis. Vol. 1, pp. 11-27.

23.Lai, N. M., Nalliah, S., Jutti, R. C., Hla, Y. Y., Lim, V. K. E. 2009. The Educational Environment and Sef-Percieved Clinical Competence of Senior Medical Students in a Malaysian Medical School. Education for Health Change in Leraning \& Practice. 22(2).

24.Lowrance, W. 1976. Of Acceptable risk - Science and the Determination of Safety. Los Altos, CA: William Kaufmann Inc.

25.MS ISO 31000:2010, Risk management - Principle and Guideline, Department of Standard Malaysia. 
26. National Association of College and University Business Officers 2009. Results of the National Campus Safety and Security Project Survey. NACUBO, APPA, et al.

27. Ochoa, X. 2015. Visualizing Uncertainty in the Prediction of Academic Risk. http://ceur-ws.org/Vol-1518/paper1.pdf

28. Office of the Chancellor of UA Little Rock 2019. Policy on Risk Management216.1. The University of Arkansas at Little Rock.

29. Project Management Institute 2017. A Guide to the Project Management Body of Knowledge (PMBOK Guide). $6^{\text {th }}$ Edition.

30. Project Management Institute. 2013. A Guide to The Project Management Body of Knowledge (PMBOK Guide) (Project Management Institute).

31. Raanan, Y. 2009. Risk Management in Higher Education- Do We Need It? Research Gate.

32.Renn, 0. 2005. Risk Governance. White Paper No. 1, International Risk Governance Council, Geneva.

33. Rosa, E. A. 2003. The Logical Structure of the Social Amplification of Risk Framework (SARF): Metatheoretical Foundation and Policy Implications. In N. Pidegeon, R.E. Kaspersen and P. Slovic (eds) The Social Amplification of Risk. Cambridge: Cambridge University Press.

34. The University of North Carolina at Chapel Hill 2016. Risk Management Policy. The University Policy Manual

35. The University of Sydney 2017. Risk Management Policy. Australia. https://www.sydney.edu.au/policies/showdoc.aspx?recnum=PDOC2011/227\&R endNum $=0$

36. Toma, S. V., Alexa, I. V., Sarpe, D. A. 2014. Identifying the Risk in Higher Education Institutions. Emerging Markets Queries in Finance and Business. Procedia Economics and Finance 15. doi: 10.1016/S2212-5671(14)00520-6.

37.Tuncel G., Alpan G. 2010. Risk Assessment and Management for Supply Chain Networks: A Case Study, Computers in Industry (61), 250-259.

38. Willson, C., Negoi, R., Bhatnagar, A. 2010. University Risk Management. The Internal Auditor, 67(4), 65-68.

39. WSU Risk Management Services (RMS) 2020. Policy on Risk Management, Executive Policy \#6. Washington State University. 


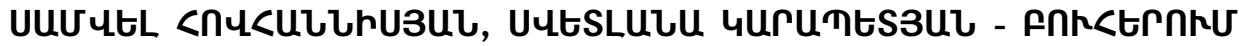

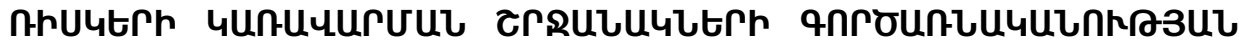
¿กトกर

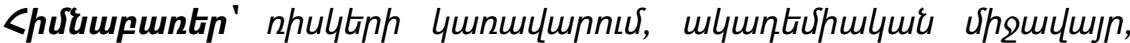

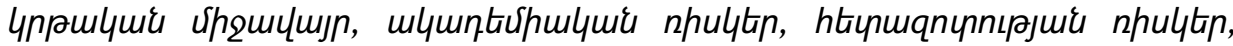

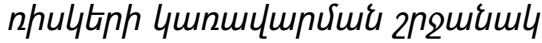

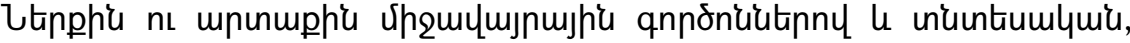

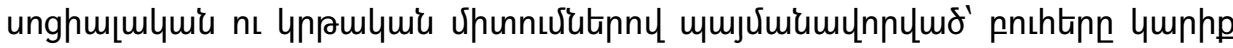

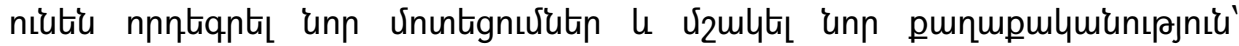

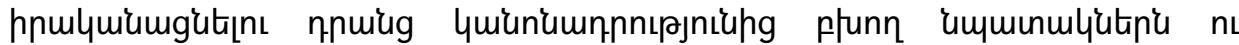

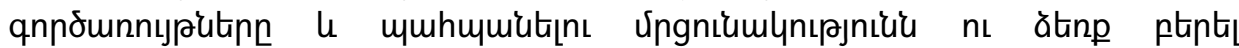

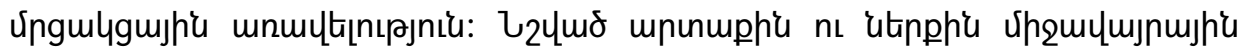

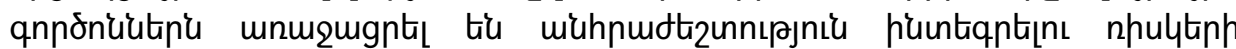

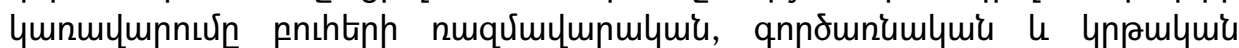



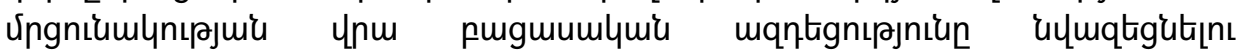

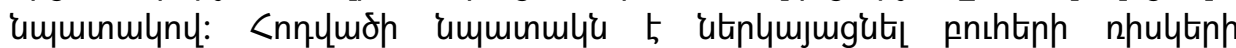

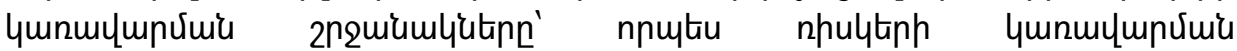

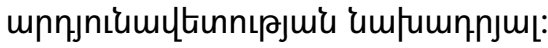

\section{САМВЕЛ ОВАНИСЯН, СВЕТЛАНА КАРАПЕТЯН - О ФУНКЦИОНАЛЬНОСТИ ФРЕЙМВОРКОВ УПРАВЛЕНИЯ РИСКАМИ В УНИВЕРСИТЕТАХ}

Ключевые слова: управление рисками, академическая среда, образовательная среда, академические риски, исследовательские риски, фреймворк управления рисками

Вузам необходимо применять новые подходы и развивать новую политику для реализации своих уставных целей и функций, поддерживать конкурентоспособность и получить конкурентное преимущество, что обусловлено фракторами внутренней $и$ внешней среды, а также экономическими, социальными и образовательными тенденциями Эти факторы внешней и внутренней среды привели к необходимости интегрировать управление рисками в стратегические, оперативные и академические процессы вуза с целью снижения негативного влияния на эффективность деятельности и конкурентоспособности. Цель данной статьипредставить фрреймворк управления рисками в контенте вузов как предпосылку эффрективности управления рисками. 